\title{
Aktivitas Public Relations Dalam Upaya Meningkatkan Citra Taman Wisata Candi Borobudur
}

\author{
1) Julita Monica Angelica Raturoma, ${ }^{2)}$ Lina Sinatra Wijaya \\ Fakultas Teknologi Informasi Universitas Kristen Satya Wacana \\ Jalan Diponegoro 52-60, Salatiga 50711, Jawa Tengah, Indonesia \\ Email: ${ }^{1)}$ 602014011@student.uksw.edu, ${ }^{2)} \underline{\text { lina.sinatra@ @staff.uksw.edu }}$
}

\begin{abstract}
Abstrak
Indonesia merupakan salah satu tujuan wisata didunia. Karena itu, pariwisata di Indonesia harus dibangun dan dikembangkan. Taman Wisata Candi (TWC) Borobudur sebagai salah satu tempat wisata dengan keindahan dan kemegahannya, menjadi daya tarik untuk semua orang. Tujuan dari penelitian ini adalah untuk mengetahui apakah aktivitas Public Relations yang dilakukan selama ini sudah berpengaruh pada peningkatan citra di Taman Wisata Candi Borobudur atau belum. Penelitian ini menggunakan metode penelitian deskriptif kualitatif. Data dikumpulkan melalui wawancara dan observasi. Target dari penelitian ini adalah pengunjung dan humas TWC. Hasil dari penelitian ini menunjukan bahwa kegiatan internal yang dilakukan oleh Public Relations Taman Wisata Candi Borobudur seperti employee relations, darmawisata, majalah internal, kontak pribadi, olahraga dan kegiatan eksternal dilakukan seperti hubungan dengan pelanggan, komunitas dan pers. Semua kegiatan tersebut untuk menarik konsumen, menjaga hubungan dengan pihak internal dan ekternal serta membangun citra positif. Selain itu, dengan memberikan pelayanan yang baik untuk masyarakat/konsumen dan memberikan bantuan sosial serta menciptakan lapangan kerja bagi masyarakat, akan memberikan dampak positif bagi masyarakat dan semua ini akan meningkatkan citra TWC Borobudur.
\end{abstract}

Kata Kunci: aktivitas Public Relations, peningkatan citra

\section{Abstract}

Indonesia is one of the world's tourist destinations. Therefore, Indonesian tourism must be built and developed. Taman Wisata Candi (TWC) Borobudur as one of the tourist attractions with its beauty and its grandeur, becomes the main attraction for all people. The purpose of the research is to find out whether public relations activities conducted by the TWC has some impacts on the increase of Taman Wisata Candi Borobudur's image or not. This is a descriptive qualitative research. The data was gathered through interview and observation. The target audience of this research is vistors and public relations officer of TWC. The result of this research shows that the internal activities conducted by Public Relations officer of Taman Wisata Candi Borubudur are employee relations, field trip, internal magazine, personal contact, sport and the external activities conducted are customer relations, community and pers relations. All of the activities aim to attrack consumers, maintain the relationship with internal and external public and build a positive image. Besides that, by Giving good services for society/consumers and providing social assistance as well as creating employment for the society will give a positive impact towards the society, and this can improve the image of TWC Borobudur.

Keyword: Public Relations Activities, increase image

1) Mahasiswa Jurusan Public Relations Fakultas Teknologi Informasi Universitas Kristen Satya Wacana

2) Staff Pengajar Public Relations Fakultas Teknologi Informasi Universitas Kristen Satya Wacana 